\title{
CARL LUDOLF GRIESBACH, C.I.E., F.G.S.
}

\author{
Born December 11, 1847. \\ Died APril 13, 1907.
}

IT is with deep regret that we record the death of Mr. C. L. Griesbach, C.I.E., F.G.S., late Director of the Geological Survey of India, from July 17th, 1894, to February 24th, 1903.

Mr. C. L. Griesbach was born in Vienna on December 11th, 1847, and was the eldest son of Mr. George L. Griesbach, of Zobelsberg, a British subject. Carl was educated at the University of Vienna, and was for some time engaged upon the Geological Survey of Vienna, where he acquired his experience as a field geologist and palæontologist. He commanded a German scientific expedition to East Africa 1869-70, and on his return resided in London from 1871 to 1878 , where he was engaged in scientific work; he was also a most accomplished artist. He communicated an important paper "On the Geology of Natal in South Africa" to the Geological Society (see Quart. Journ. Geol. Soc., rol. xxvii, 1871, pp. 53-71, with many illustrations prepared by himself). In 1878 he was appointed Assistant Superintendent to the Geological Survey of India, and joined in Calcutta the same year. He passed through rarious grades of promotion from 1880 to l884. From 1884 to $1886 \mathrm{Mr}$. Griesbach was employed on the Afghan Boundary Commission, with the grade of Deputy Superintendent, and was raised to first grade Superintendent in November, 1886. He was created a Companion of the Indian Empire in February, 1887. From January, 1888, to July, 1889, his services were placed at the disposal of H.H. the Amir of Kabul, and he was made a Superintendent in 1889 , and-on the retirement of Dr. William King, F.G.S.-Director of the Geological Surrey in 1894.

When resident in London he served as an Officer in the Royal London Militia, now the 6th Battalion Royal Fusiliers, and has since been retired with the rank of Lieutenant-Colonel.

A list of twenty-six scientific papers by $\mathrm{Mr}_{\mathrm{r}}$. Griesbach will be found in the Grological M Magazine for June, 1903, pp. 287-288; also of his special war services in India. Mr. Griesbach, in 1869, married Emma, daughter of the Rev. W. R. Griesbach, M.A., of Millington, Yorkshire, who died in 1892, leaving two cbildren. He has lately resided in Graz, Austria, with his daughter. His only son, Walter, is at Rerelstoke, B.C. For the last year Mr. Griesbach has been suffering from thrombosis, and although at times slightly better he succumbed to this malady on the 13 th April, at the age of 60 .

Mr. Griesbach served for twenty-five years on the Geological Survey of India. He was a Foreign Member of the k.k. Akademie der Wissenschaftlich Wien and numerous other learned societies. He was decorated for the Boundary Commission; received the Afghan medal and clasp, the Burma medal and clasp, the Nishaw-i-Hurmat (Afghan order); H.I.M. the Emperor of Austria-Hungary presented him with the Austrian gold medal in connection with the scientific expedition to the central regions of the Himalayas in 1892 . He was elected a Fellow of the Geological Society of London in 1874. 